\title{
Experiences in Developing and Implementing a Capstone Course in Information Technology Management
}

\author{
Daniel Brandon, James Pruett, and Jim Wade \\ Christian Brothers University, Memphis, TN, USA
}

\author{
dbrandon@cbu.edu
}

\section{Executive Summary}

With business and technology complexity increasing rapidly, information technology management departments are attempting to deal with the challenge in a variety of ways. One approach is through the deployment of a nonstandard, comprehensive, finishing course, a so-called capstone information technology management (ITM) course. This paper describes the experiences of faculty members at Christian Brothers University in developing and implementing a capstone course in information technology management. In addition, the paper presents the rationale on which the course is based and reviews how other similar information technology departments have addressed the issue.

Beginning with a brief introduction to the importance of Information Technology Management in today's world, the paper presents a compelling case for why this course is needed. The discussion includes statements of support by industry leaders as well as factual studies pointing out the lack (and often, the failure) of proper emphasis being placed in this area by business schools. The conclusion of this investigation is that a capstone course in Information Technology is not only required but central to successful preparation of ITM graduates for their future role in the workplace.

The paper then documents the efforts of the ITM faculty at our school, as they set about to design, develop, implement, measure and incorporate a capstone course on Information Technology Management into their ITM curriculum. Significant detail is provided on the design concepts and how they were carefully chosen to incorporate ISCC recognized guidelines into the course. The approach was to ensure that students completing it would be well prepared for their ITM career choices and for pursuing advanced degrees. The paper presents conclusions in a tabular form to highlight the goals, design objectives, and the deficiencies these objectives and goals are designed to correct.

Implementation is discussed along with two methods of implementation deployed by different faculty members at $\mathrm{CBU}$ to accomplish those design goals. Along with the implementation strategies, the pitfalls and problems are discussed as an aid to others interesting in developing this type course. Included in this discussion are measurement methods deployed and their success/failure aspects. The issue of a final core competency exam is explored along with a final discussion of early results comparing the exam to the project approach as a method for

Material published as part of this journal, either on-line or in print, is copyrighted by the publisher of the Journal of Information Technology Education. Permission to make digital or paper copy of part or all of these works for personal or classroom use is granted without fee provided that the copies are not made or distributed for profit or commercial advantage AND that copies 1) bear this notice in full and 2) give the full citation on the first page. It is permissible to abstract these works so long as credit is given. To copy in all other cases or to republish or to post on a server or to redistribute to lists requires specific permission and payment of a fee. Contact Editor@JITE.org to request redistribution permission. evaluation of student performance.

In conclusion the paper summarizes what has been learned by the faculty at CBU during the development of this capstone course and how other universities have attempted to resolve this issue. A table of different approaches by a variety of other colleges and universities is presented to aid the reader in developing a better understanding of the complexity of this type of course development. While this paper is not a panacea to cure all 
the ills of course development in this area, it does offer one perspective on why it should be done, how it was designed, measured, and the results which were achieved. The premise is: this should better prepare the reader to understand the issues and the practical side of development of an Information Technology Management capstone course for their institution.

Keywords: ITM, Capstone, Senior, Course, Undergraduate, Learning, Comprehensive, Project

\section{Introduction}

The signs are all around us.

- "Hailed as a savior when he arrived at AT\&T three years ago, CEO C. Michael Armstrong quickly made $\$ 120$ billion worth of acquisitions to position the company for the digital era. Now, amid a steep decline in its share price, Armstrong is separating the company into four pieces." (Rosenbush, 2001)

- 'I guarantee that if you were a fly on the wall at almost any board meeting, you'd hear the same kinds of questions: 'I wonder how we can do more business over the Internet? What kind of intranet will best serve our needs? How can we better communicate with and manage our suppliers? How can we get closer to our customers?"' (Maruca, 2000)

- In 2000, Wipro Industries increased their profits by more than $100 \%$ over 1999 and has recently won contracts with General Electric, Home Depot, and Nokia. According to Vivek Paul, Wipro's CEO, their goal is to challenge IBM Global Consulting, Accenture, and Electronic Data Services as a major player in the business/information systems consulting industry. What makes this claim significant is that Wipro is based in Bangladesh, India. (Einhorn, 2001)

It's a new game with new rules.

IT challenges are both growing and changing. Global organizations, supplier-to-customer supply chain connectivity, mergers, acquisitions, divestitures, outsourcing, and major e-business components are all standard fare in today's business environment. Information technology has become strategic to many businesses and essential to virtually all businesses. The need is clear. Never has there been a better time to be an information technology management major. However, a number of studies have questioned whether or not graduates of information technology management undergraduate programs possess the proper balance of technical, business, and interpersonal skills to allow them to immediately contribute after moving into today's business environment. (Chow et. al., 1994; Alexander, 1996; Coffee, 1998)

In fact, there is evidence that formal undergraduate information technology education is coming up short. According to a survey of 1,250 IT users, $78 \%$ of those interviewed thought encouraging people to study IT full-time was the best way to deal with the IT problem. Ironically, despite this response, only $20 \%$ of the IT managers interviewed "thought undergraduates were equipped for work." (Kennedy, 1998) Other studies have found a similar lack of preparation on the part of information technology graduates. (McGee, 1998; Buckingham, 1987)

According to a study sponsored by the National Science Foundation (NSF), "Large software and hardware systems continue to fail despite rapid advances in information technology... [and] the problem is even deeper than reported. Failures of complex information systems are generally not reported by industry. Within the companies where these failures occur, the valuable lessons to be learned by these failures rarely are reported or examined. In academe, exploring the reasons for these failures is not addressed. Graduates are not prepared to cope with the complexity of medium to large systems... Something is amiss in the nation's ability to generate well prepared new graduates in the information systems-centric 
disciplines." (Lidtke, 1999) The NSF-sponsored study identified several skill deficiencies: (1) inability to solve problems relating to medium and large computing systems; (2) inability to apply systemic thinking to complex computing systems; (3) deficiencies in business case preparation and assessment in computing systems applications work; and, (4) inadequate written, verbal, group and listening skills.

The NSF study also identified three categories of industry-defined attributes an IT graduate should possess: (1) personal skills, including problem-solving and critical-thinking skills, persistence, and curiosity; (2) interpersonal skills, including collaborative and communication skills (verbal, written, listening, group); and, (3) technical knowledge and skills, including systems development skills and application capabilities. Gupta identified a similar list and added a fourth category: business functional knowledge, including the ability to interpret business problems, develop appropriate technical solutions, and understand the business environment. (Gupta, 1998)

This paper deals with one aspect of a potential solution: the capstone ITM course. More specifically, the paper describes the capstone course (ITM 455) developed and implemented by faculty members in the Information Technology Management Department at Christian Brothers University. While ITM 455 is intended as the IT capstone course, it is nevertheless only one course in the ITM curriculum. The ITM curriculum offers students a combination of both core business courses (Economics, Statistics, Accounting, Management, Marketing, Law, Ethics) and computer science courses. (It is worth noting that (1) ITM is only one specialization at the bachelor degree level in the School of Business at Christian Brothers University and (2) all bachelor degree students, including those in ITM, take Business Policy, the School of Business "capstone course.") In this paper, the components of ITM 455, the logic behind its development, and the issues encountered in delivering it are presented. In addition, an overview of how other ITM-type departments have addressed the same question is included.

\section{Background}

The idea of including a capstone course in a degree program is, of course, not new; nor is the idea of a capstone course in the ITM or MIS specialization area. The value of a capstone course for a degree program (such as a BSBA) has been evaluated, tried, and generally recommended. (Magner, 1990; Magner, 1992; Boyer, 1998; Thomas, 1998; Gardner, 1998; Heinemann, 1997; Jessup, 1995) A number of journal articles and conference proceedings have addressed this topic as it relates to more technical curricula, such as computer science or computer engineering. (Merts, 1997; Magney, 1996; Codespoti, 1994) However, considerably less literature has addressed issues related to a capstone course in a combination business and technology setting. (Novitzki, 1998; Gupta, 1998; O’Neil, 1998) It is in this latter area, a combined business and information technology environment, that this paper is focused.

\section{Design}

Christian Brothers University's Information Technology Management (i.e., CBU ITM) curriculum is based somewhat on the National Science Foundation sponsored "Information Systems-Centric Curriculum (ISCC) Program Guidelines" (Lidtke, 1999), although a course-by-course match is clearly not exact. Table 1 below shows a comparison.

The CBU Information Technology Management curriculum also includes several other technical courses appropriate for today's professional information technology environment: ITM 152 - Introduction to Information Technology, ITM 153 - Basic IT Applications (word processing, spreadsheet, presentation), and a choice from several electives including: ITM 280 - Operating Systems, ITM 457 - Internet Programming, ITM 456 - Java Programming, and ITM 492 - Advanced Communications Networks. 


\begin{tabular}{|l|l|}
\hline \multicolumn{1}{|c|}{ ISCC Program Guideline } & \multicolumn{1}{c|}{ CBU ITM Course } \\
\hline ISCC 41 - Database & ITM 451 - Database Design \\
\hline ISCC 42 - Computer Interaction Methods & ITM 255 - C/C++ Programming \\
\hline ISCC 43 - Telecommunications/Networks & $\begin{array}{l}\text { ITM 291 \& 292 - Telecommunications } \\
\text { /Networks }\end{array}$ \\
\hline ISCC 44 - Dynamics of Change & $\begin{array}{l}\text { No single course, although covered to some } \\
\text { degree in multiple courses }\end{array}$ \\
\hline $\begin{array}{l}\text { ISCC 45 - Applications of Artificial Intel- } \\
\text { ligence }\end{array}$ & $\begin{array}{l}\text { ITM 480 - Decision Support Systems } \\
\text { (which includes artificial intelligence and } \\
\text { expert systems) }\end{array}$ \\
\hline ISCC 51 - Distributed Systems & $\begin{array}{l}\text { Covered in ITM 351 - Systems Analysis \& } \\
\text { Design and ITM 451 - Database Design }\end{array}$ \\
\hline ISCC 52 - Computer Ethics & $\begin{array}{l}\text { Covered in ITM 250 - Introduction to In- } \\
\text { formation Technology and ITM 455 - } \\
\text { Information Systems Management (cap- } \\
\text { stone) }\end{array}$ \\
\hline ISCC 53 - Enterprise Systems & $\begin{array}{l}\text { Covered in ITM 351 - Systems Analysis \& } \\
\text { Design, ITM 451 - Database Design, and } \\
\text { ITM 455 - Information Systems Mgmt }\end{array}$ \\
\hline ISCC 61 - Comprehensive Project & $\begin{array}{l}\text { ITM 455 - Information Systems Mgmt } \\
\text { (capstone) }\end{array}$ \\
\hline
\end{tabular}

Table 1. ISCC Program Guidelines versus CBU ITM Courses

For a "capstone course," ISCC Guidelines present "ISCC 61: Comprehensive Collaborative Project" as the concluding course in its sequence. The ISCC 61 description states, "This course will provide a summative experience for the student... will require ... participation in a team activity producing working systems from real world specifications ... [and] ideally ... will be done in collaboration with an industry system development team working on a complex systems development project." In line with these guidelines, the ITM Department faculty designed its capstone course (ITM 455) to explore and put to practical use the entire body of knowledge gained in previous ITM courses. ITM 455 was formulated around the following educational outcomes:

1. Competency in relating business and ITM, including the ability to assess potential business problems and, if appropriate, propose/develop solutions supported by information technology.

2. Competency in the core disciplines of ITM, including systems analysis/design, database, application development, and telecommunications for the resolution of business issues.

3. Competency in important supporting areas, including creativity/critical thinking, writing, presenting, and the ability to work as part of a team.

Clearly defining a course at the conceptual level, however, is a far cry from implementing one successfully. 


\section{Approach}

As an overview statement, ITM 455 is focused first on business issues as they relate to IT, plus IT leadership and management preparation. The CBU course differs from the ISCC 61 course in that it is not a development course, but rather a professional-life-in-IT preparation course. In line with this perspective, students taking the IT capstone course are expected to exhibit a different, more business-like perspective and atypical student behavior patterns (e.g., punctuality, professional decorum, and active participation in class discussions). As one ITM faculty member stated with regard to the course and the professional world senior ITM students are about to enter, "We aren't in the business of perpetrating myths."

Table 2 presents the major course components of ITM 455, the goals addressed by each component, the approaches taken to address these goals, and the NSF-identified deficiencies each goal addresses. By design, ITM 455 is unique. Its emphasis is not on technology or techniques, but instead focuses on major IT issues and the business environment where much of IT takes place.

\begin{tabular}{|c|c|c|c|}
\hline Emphasis & Goal & Approaches & Deficiency Addressed \\
\hline $\begin{array}{l}\text { Business \& } \\
\text { IT Issues } \\
\text { and Trends }\end{array}$ & $\begin{array}{l}\text { Increased knowl- } \\
\text { edge of business } \\
\text { and IT reality } \\
\text { (e.g., realities of } \\
\text { managing IT } \\
\text { globally) }\end{array}$ & 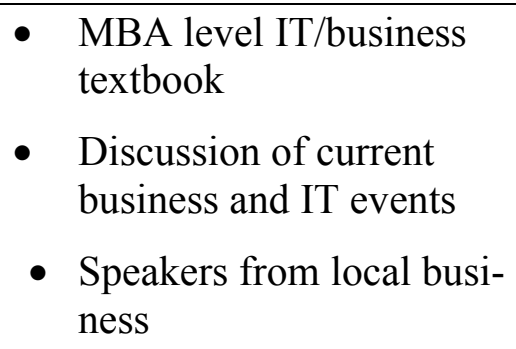 & $\begin{array}{l}\text { Deficiency 1: Increased } \\
\text { awareness of actual medium } \\
\text { and large-scale information } \\
\text { technology and business } \\
\text { problems }\end{array}$ \\
\hline $\begin{array}{l}\text { Business } \\
\text { Case Studies }\end{array}$ & $\begin{array}{l}\text { Ability to analyze } \\
\text { specific business } \\
\text { and IT challenges } \\
\text { (e.g., implementa- } \\
\text { tion of ERP sys- } \\
\text { tem) }\end{array}$ & $\begin{array}{l}\text { Numerous case studies, } \\
\text { essentially one per } \\
\text { IT/business topic }\end{array}$ & $\begin{array}{l}\text { Deficiencies } 2 \text { and 3: Oppor- } \\
\text { tunity to employ systemic } \\
\text { thinking to complex comput- } \\
\text { ing questions and practice in } \\
\text { business case preparation } \\
\text { and assessment }\end{array}$ \\
\hline $\begin{array}{l}\text { Written As- } \\
\text { signments }\end{array}$ & $\begin{array}{l}\text { Ability to create } \\
\text { professional writ- } \\
\text { ten documentation } \\
\text { (e.g., executive } \\
\text { summary) }\end{array}$ & 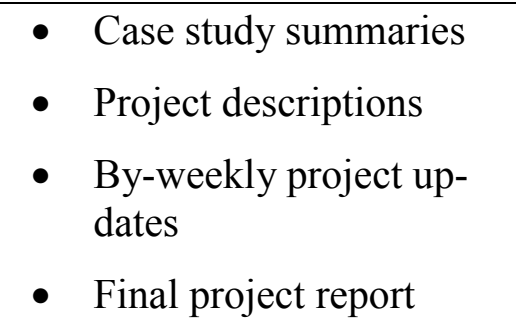 & $\begin{array}{l}\text { - Deficiency 4: Opportunity } \\
\text { to address deficiencies in } \\
\text { written, verbal, group, and } \\
\text { listening skills }\end{array}$ \\
\hline $\begin{array}{l}\text { Verbal Re- } \\
\text { porting }\end{array}$ & $\begin{array}{l}\text { Ability to make } \\
\text { professional ver- } \\
\text { bal presentations } \\
\text { - with or without } \\
\text { slides }\end{array}$ & $\begin{array}{l}\text { - Facilitation of case study } \\
\text { discussion } \\
\text { - Project updates } \\
\text { - Project presentations. }\end{array}$ & $\begin{array}{l}\text { Deficiency 4: Opportunity } \\
\text { to address deficiencies in } \\
\text { verbal skills }\end{array}$ \\
\hline
\end{tabular}




\begin{tabular}{|c|c|c|c|}
\hline $\begin{array}{l}\text { Discussion } \\
\text { Participation }\end{array}$ & $\begin{array}{l}\text { Ability to engage } \\
\text { in group discus- } \\
\text { sions without de- } \\
\text { finitive answers } \\
\text { (e.g., outsourcing) }\end{array}$ & $\begin{array}{l}\text { - Case study discussion } \\
\text { - Discussion with guest } \\
\text { speakers } \\
\text { - Feedback to other stu- } \\
\text { dents }\end{array}$ & $\begin{array}{l}\text { Deficiencies } 2,3 \text {, and } 4 \text { : } \\
\text { Opportunity to employ sys- } \\
\text { temic thinking to complex } \\
\text { computing questions, op- } \\
\text { portunity to practice busi- } \\
\text { ness case preparation and } \\
\text { assessment, and opportunity } \\
\text { to address deficiencies in } \\
\text { written, verbal, group, and } \\
\text { listening skills }\end{array}$ \\
\hline $\begin{array}{l}\text { Team As- } \\
\text { signments }\end{array}$ & $\begin{array}{l}\text { Ability to build } \\
\text { consensus and } \\
\text { play a meaningful } \\
\text { role in joint ef- } \\
\text { forts }\end{array}$ & $\begin{array}{l}\text { - Case study preparation } \\
\text { - Possibly, project assign- } \\
\text { ment }\end{array}$ & $\begin{array}{l}\text { Deficiency 4: Opportunity } \\
\text { to address inadequate group } \\
\text { skills }\end{array}$ \\
\hline $\begin{array}{l}\text { Capstone } \\
\text { Project As- } \\
\text { signment }\end{array}$ & $\begin{array}{l}\text { Ability to grapple } \\
\text { with real busi- } \\
\text { ness/IT dilemmas, } \\
\text { successfully ana- } \\
\text { lyze situations, } \\
\text { and propose real } \\
\text { solutions }\end{array}$ & $\begin{array}{l}\text { Select appropriate busi- } \\
\text { ness situation } \\
\text { Involvement with busi- } \\
\text { ness organization, prob- } \\
\text { lem discovery, develop- } \\
\text { ment, and presentation of } \\
\text { business solution ap- } \\
\text { proach }\end{array}$ & $\begin{array}{l}\text { Deficiencies } 1,2 \text {, and } 4 \text { : } \\
\text { Opportunity to evaluate ac- } \\
\text { tual medium-size comput- } \\
\text { ing problem, opportunity to } \\
\text { employ systemic thinking to } \\
\text { the problem's complex } \\
\text { computing issues, and op- } \\
\text { portunity to address defi- } \\
\text { ciencies in written, verbal, } \\
\text { group, and listening skills }\end{array}$ \\
\hline
\end{tabular}

Table 2. ITM 455: CBU's ITM Capstone Course Design Components

\section{Implementation}

Once the course's initial design and approach were solidified, the implementation details were developed. A decision was made to select a graduate level, business/IT textbook that emphasizes the use of business cases as the primary teaching method. Lectures would be used to simply introduce and reenforce fundamental principles of information technology management. The selected cases would emphasize the practical application of these principles to a diverse set of business related situations. Students would be challenged to explore alternatives and participate in classroom discussions with their peers. The instructor would serve primarily as a moderator and discussion guide. At the conclusion of each case discussion, the instructor would be expected to summarize the key points made, the case lessons, and the principles applied. Most of the class time would be spent in this case discussion mode, with frequent references and tie-ins to the student projects and reading materials. Examinations would be used to test student comprehension of key principles learned in class lectures, reading assignments, and case discussions. Finally, a comprehensive research project would be used to give each student an opportunity to work individually and in a team setting to develop a meaningful analysis and proposed solution to a real world problem on a topic approved by the instructor.

While ITM 455 is still in its early development stage, several approaches to final projects have been used in an attempt to create this required outcome. In one approach, teams were formed consisting of 2 or 3 students. Each team met, selected an industry, and proposed a study, which was then reviewed and approved by the instructor. Each individual team member then selected one company in that industry 
and developed a comprehensive research report on that company. Each report focused on the web presence of the company. Comprehensive analysis of the company's web site was required. Students were expected to determine the mission of the company, its organizational style and the purposes of its web presence (i.e., whether it was e-commerce, institutional, investment oriented, informational, employment oriented, etc.). The critical review was also expected to assess the web site's applicability to corporate mission and purpose, its complementary themes, the quality of information provided, its ease of use, the audience intended, and other key characteristics. Bi-weekly team meetings were required to ensure progress throughout the semester and to simulate a real-world project situation. Individual reports had a minimum length requirement of 16 pages.

Once the individual and team reports were complete, the teams would reconvene to present their research to the other teams. The combining of presentations of individual student research with team research has produced some interesting outcomes, not the least of which is that students learn (sometimes reluctantly) that with effort they are able to work successfully both as an individual and as a team member, and that the team can accomplish the research project objectives.

As a next step, each team was required to jointly develop a presentation for a "virtual" company in the team's chosen industry, with the virtual company expected to embody the best features of the companies surveyed. The "development" of the virtual company included creation of a mission statement, "realistic" company financial statements, a web-page design, a description of the web site's target audience, a justification for the company's web design model, and the development of a prototype web site. As a concluding activity, each team was required to present its web site and accompanying organizational description to the entire class.

While this approach to project work has several positive aspects, there are also challenges.

- Expectations: One challenge is the need to set proper student expectations for both the work effort required and an acceptable outcome. This has typically been accomplished with a minimum expenditure of class time by bringing high-quality project reports from prior semesters to class and allowing a 15-minute "lab time" in which current student teams are allowed to review the reports. Currentsemester students are not allowed to copy the reports or take them out of the classroom.

- Teamwork: A second challenge is that of teamwork. How must assignments be structured to ensure that all individual students contribute in the team setting? One method that has been employed to aid this process is the requirement that each team submit a minimum of three team progress reports, with each team member responsible for at least one report. The reports (which can be submitted by email) must show the team's meeting dates, as well as listing the members present and absent, along with the reasons for the absences. In addition, the report must show each meeting's agenda, individual project assignments and accomplishments, and must provide an overall project status update.

An alternative project approach required students to develop IT-business focused case studies based on slightly modified versions of actual business situations faced by local companies. In summary, course instructors are aware of the challenge required to develop meaningful project assignments and are continuing to evaluate reasonable project-oriented alternatives. It is quite possible that no one model will ever be specified. On a practical note, using multiple models discourages passing along class notes and solutions to upcoming students and encourages original thinking.

\section{Core Competency Exam}

In addition to the course requirements for ITM 455 mentioned earlier, the ITM Department also administers a Core Competency Exam at the conclusion of ITM 455. The exam is voluntary and has no grade impact on the individual student. The purpose of this exam is to assess ITM graduating senior competency in key subject areas. The exam is a 50-question, multiple-choice exam. Questions are taken from 
sample questions included in the CCP (Certified Computing Professional) and ACP (Associate Computing Professional) Review Outlines published by the ICCP (Institute for Certification of Computing Professionals). The results of this examination are tabulated by academic subject areas and then used as indicators of departmental and school strengths and weaknesses. Thus, currently, the ITM 455 Final Project and the ITM 455 Competency Examination are the two "objective" methods of evaluating the effectiveness of the curriculum and associated core business courses. The ITM Department recognizes that it is in the early, formative stage of developing evaluation tools capable of measuring effectiveness.

\section{Early Results}

On the positive side, even during the first year of the course's existence, several important goals were achieved. Students are: (1) demonstrating an awareness of current business and IT issues and trends, (2) regularly preparing and presenting written and verbal reports, (3) participating in teams to complete some assignments, (4) engaging in class discussions on controversial IT issues, and (5) doing meaningful capstone IT/business related projects.

However, reality differs considerably from the original ITM faculty vision in several important ways. Students: (1) often regard the course's requirements as outside their true interests; (2) question the value of some verbal, written, and team assignments as being make-work situations; (3) tend to fight the experience, are uncomfortable with the change in typical classroom venue, and only partially embrace the learning opportunity; (4) often reluctantly engage in classroom discussions on topics that range outside known facts and into less definitive areas (e.g., strategy); and, (5) have trouble equating regular class attendance, punctuality, on-time and professionally-prepared assignments, and engaged participation in class discussions with expected professional decorum.

Our ITM students often state a desire to remain very narrowly focused. This is especially true of those students who are strongly technical in their orientation. They often neither understand nor appreciate the effect that company mission and goals, culture, organizational structure, strategic planning, management style, and other management-oriented business components have upon the successful implementation of information systems. One implicit goal is to expose such students to those subjects and their importance at some point during the capstone course experience.

\section{Other Approaches}

There is clearly no single way to handle a capstone course in information technology. Gupta presented a number of interesting approaches to be used within the capstone IT course, including "targeted assignments." One example was to have each student interview both a business functional area manager and an IT executive about the role of IT in the organization and then contrast their views. He also suggested guidelines for course success, including planning and organizing the course well in advance to ensure meaningful timing of assignments and instructional materials, expecting and planning for student frustrations, building an atmosphere of trust and mutual respect between faculty and students and among fellow students, and insisting on verbal project progress reports during class time as a means of coping with project management and client issues.

In another example of a capstone course the students completed a major project with a selected company in an IT related industry. This approach consisted of a class organized into teams who were then allowed to select from several alternatives a team project for their course work during the semester. The selected team project became the primary focus of the course for that semester. During the initial class meeting students were allowed to select an appropriate project from a list of potential projects. Next, the faculty "class manager" formed teams matching the students with each other consistent with an assessment of their skill level and experience. (Novitzki, 1998) This approach certainly offers tremendous benefit to 
the student. However, it requires extensive project management time on the part of the faculty. Extensive outside the classroom time is required to coordinate and recruit those companies willing to participate each semester. This approach was not considered due to our required class teaching load and the number of faculty in our ITM Department.

Capstone courses seem to be focused around the following approaches: (1) actual IT design and development project, (2) conceptual IT design project, (3) IT research project, and (4) IT design philosophies. Table 3 presents a sampling of business-school IT programs and describes how each one addresses the IT capstone course question.

\begin{tabular}{|l|l|l|}
\hline University & Course* & Description \\
\hline Arkansas, University of & $\begin{array}{l}\text { Business Application } \\
\text { System Development } \\
\text { (CISQ 4363) }\end{array}$ & $\begin{array}{l}\text { System design, development, and } \\
\text { implementation of real life project }\end{array}$ \\
\hline $\begin{array}{l}\text { California State University } \\
\text { (Sacramento) }\end{array}$ & $\begin{array}{l}\text { System Development } \\
\text { Life Cycle II (MIS 161) }\end{array}$ & $\begin{array}{l}\text { Second in two-course system analy- } \\
\text { sis, design, and development se- } \\
\text { quence }\end{array}$ \\
\hline Louisiana State University & $\begin{array}{l}\text { Analysis and Design of } \\
\text { Management Informa- } \\
\text { tion Systems (ISDS } \\
\text { 4125) }\end{array}$ & $\begin{array}{l}\text { Design philosophies and techniques } \\
\text { for the creation of information sys- } \\
\text { tems; conceptual design of actual } \\
\text { systems }\end{array}$ \\
\hline Miami University (Ohio) & $\begin{array}{l}\text { Capstone in Manage- } \\
\text { ment Information Sys- } \\
\text { tems (MIS 495) }\end{array}$ & $\begin{array}{l}\text { Extensive research, reading, writing, } \\
\text { and discussion; independent research } \\
\text { project on topic and company from } \\
\text { management MIS perspective }\end{array}$ \\
\hline Minnesota, University of & $\begin{array}{l}\text { Information Services } \\
\text { Management (IDSc } \\
\text { 4204) }\end{array}$ & $\begin{array}{l}\text { IT functions, roles, and organiza- } \\
\text { tional structures, including IT plan- } \\
\text { ning, strategy, operations, outsourc- } \\
\text { ing, acquisition, and user support }\end{array}$ \\
\hline \multicolumn{2}{|l|}{$\begin{array}{l}\text { Business System Devel- } \\
\text { opment (MIS 374) }\end{array}$} & $\begin{array}{l}\text { Full range of development is cov- } \\
\text { ered; real world client projects }\end{array}$ \\
\hline $\begin{array}{l}\text { * Courses listed are "last courses" in IT curricula, apparently (though not necessarily) cap- } \\
\text { stone IT courses; among those listed, only Miami University (Ohio) has an explicitly stated } \\
\text { capstone IT course; survey based on review of online catalog descriptions }\end{array}$ \\
\hline
\end{tabular}

Table 3. Capstone IT Courses at Selected Universities

\section{Summary}

The challenges of developing and implementing a successful IT capstone course are nearly as numerous as the challenges of successfully deploying IT in a business environment. At CBU, the challenge is still relatively new, but no less formidable. While the current CBU approach has been described (see Table 2), one part of the ongoing question deals with how the course should be structured. Gupta described an approach utilizing a team-teaching methodology and questioned whether or not the development project should be extended over two semesters (see California State University, Table 3). The answers to such questions are not simple. CBU faculty considered combining the course with a concurrent intern assignment and with blending the course with assignments based on learning a "small" ERP system that 
would be implemented on our department's server. (Note: A business internship course is already available as BUS 400.)

A second part of the question deals with how the course should be conducted. ITM 455 faculty members have begun to accept that this course will probably not ever be "smooth." Students come to the end of their undergraduate studies with too much variety in their backgrounds and in their career goals and expectations for that to occur. Departmental goals for the course, however, are far beyond achieving smooth sailing. The objective is to create a challenging, stretching, truly meaningful, summary learning experience for the graduating Information Technology Management student, to force students to expand her or his perspective at least in part by changing the approach. Felder described the difficulties of moving from the classical learning model to an active learning environment. (Felder, 1995) After changing to an approach that placed more of the responsibility for active learning on the student, Felder observed resistance to change that led him to conclude that students passed through the traditional stages of grief and trauma as they moved to the new learning environment (i.e., shock, denial, strong emotion, resistance/withdrawal, surrender/acceptance, struggle/exploration, return to confidence, and integration/success). Similar responses must be expected of ITM capstone class students as well.

A third part of the question deals with metrics. Is the course really working? Are Christian Brothers University's ITM graduates well equipped to compete in today's business environment? What parts of the curriculum can be changed to better equip the next group of students for the challenges ahead? Gupta stated, "Information systems academic programs must continually monitor industry to ensure that graduates can acquire the mix of skills necessary to perform competitively in the job market. Further, academic institutions offering IS programs must assure the hiring firms that their IS graduates have competencies to support the firm's organizational initiatives." Because the needs of business continue to change, so must business IT curricula. The measurement approaches associated with ITM 455 to date represent a minimal beginning. While they have been helpful in focusing attention on internal strengths and shortcomings, they do not address external realities. It may be that these are best measured by the achievements of our graduates that can only be measured by observation over time. Regardless, ongoing curriculum and learning experience review, including regular interaction with business and IT leaders, will always be an important part of the improvement process.

A fourth part of the question deals with intangibles. Years ago, a trusted colleague succinctly stated, "The problem we teachers have is that we spend too much time answering questions the students don't have." A major challenge in today's educational environment is that, because the questions have changed so much - and so fast, "we teachers" no longer have the answers. Like the students, teachers also struggle with the environment and the growing complexity of the questions. Yet the challenge remains. How do undergraduate information technology management programs best equip students to face an uncertain "real" world? How do teachers meaningfully interact with - "teach" - students in a world whose rules and boundaries are often uncertain and beyond anyone's understanding? An evolving capstone ITM course provides a setting for meaningful dialogue and opportunities for nonstandard learning.

These are challenging times. It is apparent that the relative academic and business stability of times past are just that, historical. As such, approaches to education must be meaningful, continually revised, and no less "dated" than today's news. The alternative is obsolescence, irrelevance, and extinction. The ITM capstone course represents the last opportunity ITM faculty members have to contribute in a creative way to the ITM major's undergraduate career. By its last-course placement, the capstone course will always be fraught with considerable challenge. Nevertheless, regardless of how it is structured, conducted, and measured, the course should serve as a final reminder for the soon-to-be graduate. "This is what you've learned. This is what it's all about. Go out with confidence. You are ready. Good luck." 


\section{References}

Alexander, S. “A Buyer's Market: Jobs Abound for IS Professionals with the Right Skills”, Computerworld, January 8, 1996.

Boyer Commission on Educating Undergraduates in the Research University, "Reinventing Undergraduate Education: A Blueprint for America's Research Universities", Carnegie Foundation for the Advancement of Teaching, January 1998.

Buckingham, R. A., Hirschiem, R.A., Land, F.F., \& Tully, C.J. Information Systems Education: Recommendations and Implications, Cambridge University Press, Cambridge, 1987.

Chow, J., Dick, G., \& Edmundson, R. “Industry Satisfaction with IS Graduates in the 1990's: An Empirical Study”, Proceedings of the Ninth Annual Conference of the International Academy of Information Management (1994), pp. 153-174.

Codespoti, D. J., "The Capstone of the C.S. Major", Proceedings of the Annual National Educational Computing Conference, Boston, MA, June 13-15, 1994.

Coffee, P. "Buying into E-Commerce", PC Week, February 2, 1998, pp. 27-32.

Einhorn, B., Kripalani, M., \& Engardio, P., "India 3.0," Business Week, February 26, 2001.

Felder, R. M., “Active Learning: Who Said It Was Easy?” Chemical Engineering Education, Vol. 29, No. 1, pp. 32-33, 1995.

Gardner, J. N. \& Van der Veer, G. The Senior Experience. Facilitating Integration, Reflection, Closure, and Transition, Jossey-Bass, Inc. Publishers, 1998.

Gupta, J. N. D. \& Wachter, R. M. “A Capstone Course in the Information Systems Curriculum,” International Journal of Information Management, Vol.18, No. 6, pp. 427-441, 1998.

Heinemann, R. L. "The Senior Capstone, Dome or Spire", Paper Presented at the Annual Meeting of the National Communication Association, Chicago, November 19-23, 1997.

Jessup, L. M. “The Senior Experience: Applied, Team Problem Solving in Business Education”, Journal of Education for Business, Nov-Dec 1995, pp. 82-86.

Kennedy, S., "Full-time Education to Overcome Skills Gap," ComputerWeekly.com, February 5, 1998.

Lidtke, D. K., et al, "ISCC '99: An Information Systems-Centric Curriculum '99 Program Guidelines for Educating the Next Generation of Information Systems Specialists, in Collaboration with Industry," supported by National Science Foundations grants, July 1999.

Magner, D. K., "Many Colleges Design Courses and Programs to Prepare Seniors to Live in the "Real World", Chronicle of Higher Education, March 21, 1990, pp. A33-35.

Magner, D. K., "At St. Mary's College Seniors Embark on Journeys within their Majors”, Chronicle of Higher Education, June 3, 1992, pp. A13.

Magney, J. "Preparing Technicians for the Managing of Technology", ATEA Journal, Apr-May 1996, pp. 8-11.

Maruca, R. F., "Are CIOs Obsolete," Harvard Business Review, Vol. 78, Issue 2, pp. 55, 2000.

Mertz, R. L., “A Capstone Design Course”, IEEE Transactions on Education, February 1997, pp. 41-46.

McGeem, M. K., “School Daze”, Information Week, February 2, 1998, pp. 44-52.

Noritz, J. "The MIS Capstone: Development on an Integrating Group Applied Project Course", Proceedings of the International Academy for Information Management

(IAIM) Annual Conference (13th, Helsinki, Finland, December 11-13, 1998), pp. 100-109.

O’Neil, S. L. \& Everett, D. R., "Information Systems Administration Course Seven. Information Systems Curriculum." Texas Higher education Coordinating Board, Houston University College of technology, January 1998.

Rosenbush, S., "Armstrong on the Record," Business Week, February 5, 2001.

Thomas, A. S., "The Business Policy Course: Multiple Methods for Multiple Goals", Journal of Management Education, August 1998, pp. 484-497.

Watson, S., “The Evolving IT Worker,” Computerworld, July 24, 2000. 


\section{Biographies}

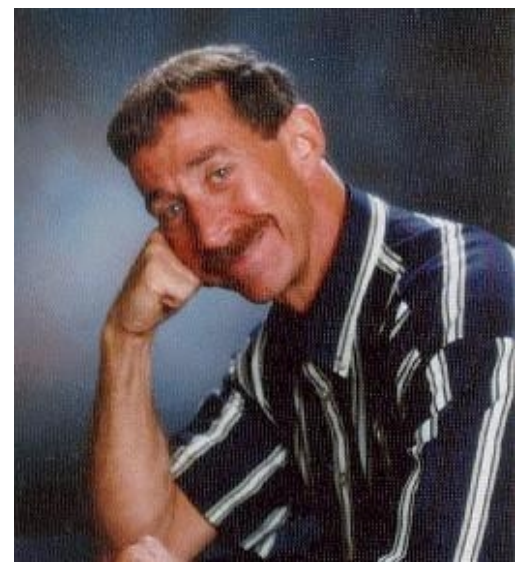

Dr. Daniel Brandon is an Associate Professor and Department Chairperson in the Information Technology Management (ITM) Department at Christian Brothers University (CBU) in Memphis, TN. His education includes a BS in Engineering from Case Western University, MS in Engineering from the University of Connecticut, and a Ph.D. from the University of Connecticut specializing in computer control and simulation. He also has the PMP (Project Management Professional) certification.

In addition to his seven years at CBU, Dr. Brandon has over twenty years experience in the information systems industry including experience in management, operations, research, and development. He was the Director of Information Systems for the Prime Technical Contractor at the NASA Stennis Space Center for six years, MIS manager for Film

Transit Corporation in Memphis for ten years, and affiliated with Control Data Corporation in Minneapolis for six years in several positions including Manager of Applications Development. He has also been an independent consultant and software developer in a several industries including: Medical, Transportation/Logistics, Finance, Law, and Entertainment.

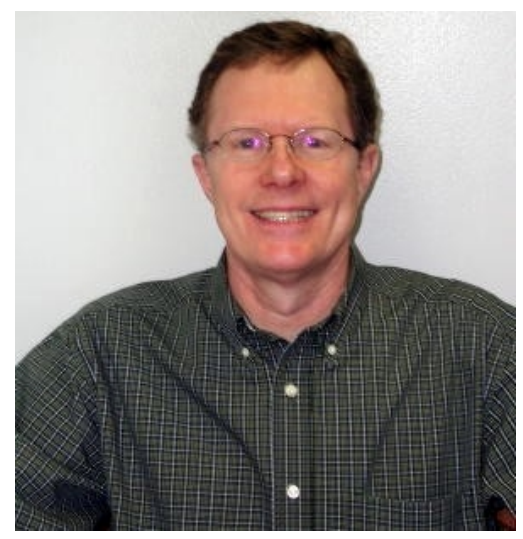

Dr. James M. Pruett is currently working with a University of Tennessee College of Nursing research team in Memphis, Tennessee. His education includes a B.S. in Industrial Engineering from Louisiana Tech University and an M.S. and Ph.D., with an emphasis in Industrial Engineering, from the University of Arkansas.

Prior to spending one year as a Visiting Professor in the Information Technology Management Department at Christian Brothers University (during which time this article was written), Dr. Pruett served as a faculty member and administrator for over 20 years in the Industrial Engineering and Information Systems \& Decision Sciences Departments at Louisiana State University and for over six years as a manager and consultant in the information technology area with International Paper.

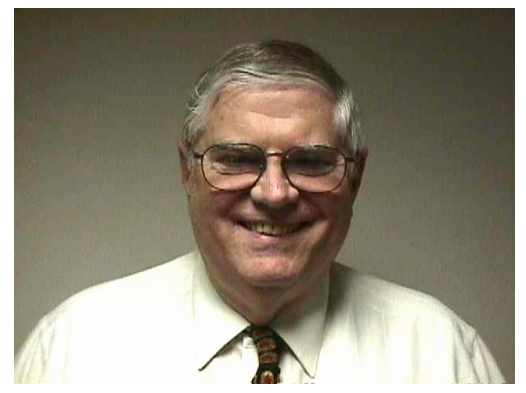

Jim S. Wade currently holds a tenured position as Associate Professor in the Information Technology Management Department at Christian Brothers University in Memphis, Tennessee. He has been at CBU for twelve years.

Prior to coming to $\mathrm{CBU}$, he was a Vice-President of Econocom International, a computer leasing company headquartered in Memphis, Tennessee. He retired from IBM with 30 years service in 1986. At IBM he held various marketing positions including Branch Manager, Senior Education Manager, and Large Accounts Marketing Manager. He has a BS Degree from the University of Florida and an MS Degree in Telecommunications Management from Christian Brothers University. 